\title{
TEKNOLOGI INFORMASI DAN KOMUNIKASI: KEDUDUKAN DAN PERANANNYA DALAM PENDIDIKAN
}

\author{
Umar \\ Dosen Tetap STAIN Jurai Siwo Metro \\ e-mail: umarstain@gmail.com
}

\begin{abstract}
Information and Communication Technology as a part of Science and Technology generally is the whole technology related to catching, collecting, storage processing, disseminating, and presenting of information. Information and Communication Technology Development has extraordinary impact in whole field of human life, include education field. The crucial problems strart from education policy which is reflected in changing curriculum, until the implementation in learning process. The others problem is the limited time allocation for presenting curriculum. Information and Communication Technology which has flexible role provide alternative solution in solving that problems.

Keywords: Information and Communication Technology, position, roles
\end{abstract}

\begin{abstract}
Abstrak
Teknologi Informasi dan Komunikasi (TIK) sebagai bagian dari Ilmu Pengetahuan dan Teknologi (IPTEK) secara umum merupakan semua teknologi yang berhubungan dengan pengambilan, pengumpulan (akuisisi), pengolahan penyimpanan, penyebaran, dan penyajian informasi. Perkembanganya membawa dampak yang luarbiasa di berbagai bidang kehidupan manusia, termasuk bidang pendidikan. Masalah krusial terjadi mulai dari kebijakan arah pendidikan yang tergambar pada perubahan-perubahan kurikulum, sampai tahap implementasinya dalam proses pembelajaran. Alokasi waktu yang terbatas untuk menyajikan muatan kurikulum yang banyak menjadi salah satu masalah yang muncul kemudian. TIK dengan kedudukan dan perannya yang sangat fleksibel menawarkan solusi alternatif untuk penyelesaian masalah tersebut.
\end{abstract}

Kata kunci: TIK, kedudukan, peranan.

\section{Pendahuluan}

Teknologi Informasi dan Komunikasi (TIK) berkembang sangat pesat, sehingga sudah merupakan gejala dunia. Teknologi sudah menjadi bagian kebudayaan Indonesia sejak dikembangkannya sistem komunikasi satelit domestik. Gejala ini sebenarnya telah menjadi perhatian sejak awal kemerdekaan, yaitu dengan digunakannya siaran radio untuk mengobarkan semangat perjuangan kemerdekaan. Marshall McLuhan (1967) seorang pakar dalam bidang sosio-kultural yang terkenal dengan bukunya, Media is the Message, menyitir ucapan Presiden Soekarno sewaktu berkunjung ke Hollywood, bahwa gambar hidup telah menyebabkan revolusi nasional di Asia. ${ }^{1}$

Salah satu bentuk produk TIK adalah internet yang berkembang pesat di penghujung abad 20 dan di ambang abad 21. Kehadirannya telah memberikan dampak yang cukup besar terhadap kehidupan umat manusia dalam berbagai

1 Yusufhadi Miarso, Menyemai Benih Teknologi Pendidikan, (Jakarta: Kencana, 2014), hal. 481. 
aspek dan dimensi. Internet merupakan salah satu instrumen dalam era globalisasi yang telah menjadikan dunia ini menjadi transparan dan terhubungkan dengan sangat mudah dan cepat tanpa mengenal batas-batas kewilayahan atau kebangsaan. Melalui internet setiap orang dapat mengakses ke dunia global untuk memperoleh informasi dalam berbagai bidang dan pada gilirannya akan memberikan pengaruh dalam keseluruhan perilakunya.

Pesatnya perkembangan TIK, khususnya internet, memungkinkan pengembangan layanan informasi yang lebih baik dalam suatu institusi pendidikan. Di lingkungan perguruan tinggi, pemanfaatan TIK lainnya yaitu diwujudkan dalam suatu sistem yang disebut electronic university (e-University). Pengembangan $e$-University bertujuan untuk mendukung penyelenggaraan pendidikan, sehingga perguruan tinggi dapat menyediakan layanan informasi yang lebih baik kepada komunitasnya, baik di dalam maupun di luar perguruan tinggi tersebut melalui internet. Layanan pendidikan lain yang bisa dilaksanakan melalui sarana internet yaitu dengan menyediakan materi kuliah secara online dan materi kuliah tersebut dapat diakses oleh siapa saja yang membutuhkan. ${ }^{2}$

Keberadaan internet saat ini merupakan suatu kebutuhan pokok manusia modern dalam menghadapi berbagai tantangan perkembangan global. Kondisi ini sudah tentu akan memberikan dampak terhadap corak dan pola-pola kehidupan umat manusia secara keseluruhan. Setiap orang atau bangsa yang ingin lestari dalam menghadapi tantangan global, perlu meningkatkan kualitas dirinya untuk beradaptasi dengan tuntutan yang berkembang. TIK telah mengubah wajah pembelajaran yang berbeda dengan proses pembelajaran tradisional yang ditandai dengan interaksi tatap muka antara peserta didik dengan pendidik baik di kelas maupun di luar kelas. Peserta didik dengan pendidik bisa melakukan proses belajar mengajar tanpa harus bertatap muka, seperti mengirim bahan pembelajaran melalui e-mail, menampilkannya atau menyampaikan materi melalui website, youtube, teamviewer, dan lain sebagainya. Paling tidak semua itu memudahkan dalam memperoleh bahan ajar, efektif waktu dan hemat biaya.

\section{Mengenal Sistem Teknologi Informasi dan Komunikasi}

Sistem teknologi informasi terbentuk karena ada hubungan dengan pengguna teknologi informasi. Sistem teknologi informasi tidak hanya mencakup hal-hal yang bersifat fisik, seperti komputer, printer tetapi juga mencakup hal-hal yang tidak terlihat, seperti software, dan mental orang (pengguna). Ringkasnya, komponen utama sistem teknologi informasi adalah

2 Daryanto, Media Pembelajaran Perannya Sangat Penting dalam Mencapai Tujuan Pembelajaran, (Yogyakarta: Gava Media, 2013), hal. 176

RI'AYAH, Vol. 01, No. 02 Juli-Desember 2016 
perangkat keras (hardware), perangkat lunak (software), dan mental-orang (brainware).

Teknologi Informasi dan Komunikasi (TIK) sebagai bagian dari Ilmu Pengetahuan dan Teknologi (IPTEK) secara umum adalah semua teknologi yang berhubungan dengan pengambilan, pengumpulan (akuisisi), pengolahan penyimpanan, penyebaran, dan penyajian informasi. ${ }^{3}$

Secara umum, teknologi informasi (Information Technology) adalah sama dengan teknologi lainnya, hanya informasi merupakan komoditas yang diolah dengan teknologi tersebut. Teknologi informasi adalah sarana dan prasarana (hardware, software, useware) sistem dan metode untuk memperoleh, mengirimkan, mengolah, menafsirkan, menyimpan, mengorganisasikan dan menggunakan data secara bermakna. ${ }^{4}$

Selain itu, Wardiana mendefinisikan bahwa teknologi informasi adalah suatu teknologi yang digunakan untuk mengolah, memproses, mendapatkan, menyusun, menyimpan, memanipulasi data dalam berbagi cara untuk menghasilkan informasi yang berkualitas. ${ }^{5}$ Artinya informasi yang relevan, akurat dan tepat waktu, yang digunakan untuk keperluan pribadi, bisnis, dan pemerintahan, serta merupakan informasi yang strategis untuk pengambilan keputusan.

Berdasarkan fungsinya, sistem teknologi informasi dibagi menjadi tiga: pertama, sistem teknologi informasi yang melekat (embended information technology system), yakni sistem teknologi informasi yang melekat dengan produk lain. Misalnya, sistem VCR (Video Casette Recorder). Dengan sistem ini, para pemakai diberi peluang untuk dapat merekam tayangan televsi. Kedua, sistem teknologi informasi yang khusus (dedicated information technology system), yaitu sistem teknologi informasi yang dirancang untuk melakukan tugas-tugas khusus. Misalnya, sistem ATM (Anjungan Tinai Mandiri). Sistem ini dirancang khusus untuk dapat melakukan transaksi keuangan bagi nasabah bank. Ketiga, sistem teknologi infornasi serbaguna (general purpose information technology system), yaitu sistem teknologi informasi yang digunakan untuk berbagai aktivitas yang bersifat umum. Misalnya, sistem komputer personal (personal computer). Sistem komputer personal merupakan sistem teknologi informasi serbaguna yang digunakan masyarakat luas. ${ }^{6}$

General purpose information technology system yang paling banyak dikembangan untuk dijadikan sebagai media dalam berbagai hal. Personal

3 Kementerian Negara Riset dan Teknologi, Buku Putih, Penelitian Pengembangan dan Penerapan IPTEK Bidang Teknologi Informasi dan Komunikasi Tahun 2005-2025, (Jakarta: Kementerian Negara Riset dan Teknologi, 2006), hal. 6

4 Bambang Warsita, Teknologi Pembelajaran, (Jakarta: Rineka Cipta, 2008), hal. 134

${ }^{5}$ Ibid, hal. 135

6 Deni Darmawan, Biologi Komunikasi; Komunikasi Pembelajaran berbasis Brain Information Comunication Technology, (Bandung: Humaniora, 2009), hal. 136

RI'AYAH, Vol. 01, No. 02 Juli-Desember 2016 
Computer dengan support berbagai software di dalamnya dapat menjadi pilihan setiap pengembang media untuk mendesain berbagai kebutuhan manusia dalam mengelola informasi. Implementasinya dalam pembelajaran sangat flesibel, flesibelitsnya dapat dilihat dari cara pengemasan informasi bahan ajar, kecepatan akses, kemudahan dalam penyajian, dan lain sebagainya.

Kaitannya dengan sistem komunikasi bahwa pengolahan informasi dan pendistribusiannya melalui jaringan telekomunikasi yang membuka banyak peluang untuk dimanfaatkan di berbagai bidang kehidupan manusia, termasuk bidang pendidikan. Ide untuk menggunakan mesin-belajar, membuat simulasi proses-proses yang rumit, serta animasi proses-proses yang sulit dideskripsikan, sangat menarik minat praktisi pembelajaran. Pelayanan pembelajaran yang tak terkendala waktu dan tempat, juga dapat difasilitasi oleh TIK. Sejalan dengan itu mulailah bermunculan berbagai jargon berawalan $e$, mulai dari e-book, e-learning, e-laboratory, e-education, e-library, dan sebagainya. Awalan e- bermakna electronic yang secara implisit dimaknai berdasar teknologi elektronika digital.

\section{Kedudukan dan Peranan Teknologi Informasi dan Komunikasi (TIK) dalam Pendidikan}

Kontribusi teori teknologi informasi dan komunikasi (TIK) dalam teknologi pembelajaran mencakup aspek infrastruktur informasi dan telekomunikasi, sumber daya manusia dan acuan atau produk hukum telematika sehingga dapat berperan untuk membelajarkan manusia dengan mengembangkan dan atau mengggunakan aneka sumber belajar.

Sebelum diuraikan apa saja peran TIK dalam pembelajaran, perlu diketahui terlebih dahulu di mana sesungguhnya letak kedudukan TIK dalam pembelajaran. Secara umum paling tidak ada dua kedudukan TIK dalam pembelajaran yaitu pertama, sebagai pendorong komunitas pendidikan untuk lebih apresiatif dan proaktif dalam maksimalisasi potensi pendidikan. Kedua, memberikan kesempatan luas kepada peserta didik dalam memanfaatkan setiap potensi yang ada, yang dapat diperoleh dari sumber-sumber yang tidak terbatas. Selain dari dua kedudukan tersebut, ada tiga kedudukan lainnya yang mengarah pada teknik operasional yaitu: 1) Mempermudah kerja sama antara pakar dan peserta didik, menghilangkan batasan ruang, jarak, dan waktu. 2) Sharing Information, sehingga hasil penelitian dapat digunakan bersama-sama dan mempercepat pengembangan ilmu pengetahuan. 3) Virtual University, yaitu dapat menyediakan pendidikan yang diakses oleh orang banyak. ${ }^{7}$

Kaitannya dengan metodologi pembelajaran yang merupakan bagian dari pembelajaran, TIK memiliki tiga kedudukan dan peranan, yaitu sebagai suplemen, komplemen, dan substitusi.

${ }^{7}$ Deni Darmawan, Teknologi Pembelajaran, (Bandung: PT. Remaja Rosakarya, 2024), hal. 5

RI'AYAH, Vol. 01, No. 02 Juli-Desember 2016 


\section{Peran tambahan (suplemen)}

Peserta didik mempunyai kebebasan memilih, apakah akan memanfaatkan materi pembelajaran melalui TIK atau tidak. Dalam hal ini, tidak ada kewajiban/keharusan bagi peserta didik untuk mengakses materi pembelajaran melalui TIK. Sekalipun sifatnya hanya opsional, peserta didik yang memanfaatkannya tentu akan memiliki tambahan pengetahuan atau wawasan. Walaupun materi pembelajaran melalui TIK berperan sebagai suplemen, dosen/guru tentunya akan senantiasa mendorong, menggugah, atau menganjurkan para peserta didiknya untuk mengakses materi pembelajaran melalui TIK yang telah disediakan.

2. Fungsi pelengkap (komplemen)

Materi pembelajaran melalui TIK diprogramkan untuk melengkapi materi pembelajaran yang diterima peserta didik di dalam kelas. Sebagai komplemen berarti materi pembelajaran melalui TIK diprogramkan untuk menjadi materi reinforcement (pengayaan) yang bersifat enrichment atau remedial bagi peserta didik dalam mengikuti kegiatan pembelajaran konvensional.

3. Fungsi pengganti (substitusi)

Beberapa perguruan tinggi di negara-negara maju memberikan beberapa alternatif model kegiatan pembelajaran/pembelajaran kepada para peserta didiknya. Tujuannya adalah untuk membantu mempermudah para peserta didik mengelola kegiatan pembelajaran/pembelajarannya sehingga para peserta didik dapat menyesuaikan waktu dan aktivitas lainnya dengan kegiatan pembelajarannya. Sehubungan dengan hal ini, ada 3 alternatif model kegiatan pembelajaran yang dapat dipilih para peserta didik, yaitu apakah mereka akan mengikuti kegiatan pembelajaran yang disajikan secara (1) konvensional (tatap muka) saja, atau (2) sebagian secara tatap muka dan sebagian lagi melalui internet, atau bahkan (3) sepenuhnya melalui internet. ${ }^{8}$

Penyebutan lain model kedua (sebagian secara tatap muka dan sebagian lagi melalui internet) adalah populer disebut blanded learning yakni model pembelajaran yang memadukan antara pertemuan di kelas (face to face) dan pembelajaran secara online. Model ini diakui sangat efektif dan efisien dalam proses pembelajaran, proses pengkayaan materi/bahan ajar oleh peserta didik dapat dilakukan secara langsung.

Sedangkan penyebutan lain model ketiga (sepenuhnya melalui internet) adalah full e-learning yaitu proses pembelajaran sepenuhnya dilakukan secara online. Seluruh rangkaian kegiatan pembelajaran mulai dari penyajian materi, interaksi diskusi (bila menggunakan metode diskusi), feedback, ujian dan penilaian semuanya dilakukan secara online. Sedangkan pertemuan di kelas (bila

8Siahaan, E-Learning (Pembelajaran Elektronik) sebagai Salah Satu Alternatif Kegiatan Pembelajaran, (Jurnal Pendidikan dan Kebudayaan, No. 042, tahun ke-9, Mei 2003)

RI'AYAH, Vol. 01, No. 02 Juli-Desember 2016 
dikehendaki) hanya penjelasan teknis pada awal pembelajaran dan pada akhir pembelajaran sebagai penutupan pembelajaran. Walapun tidak dilakukan pertemuan di kelas penjelasan teknis pembelajaran juga sesungguhnya dapat dilakukan secara tertulis dan online.

Alternatif model pembelajaran manapun yang akan disuguhkan oleh pendidik dan yang menjadi pilihan peserta didik tidak menjadi masalah dalam penilaian. Artinya, setiap peserta didik yang mengikuti salah satu model penyajian materi pembelajaran akan mendapatkan pengakuan atau penilaian yang sama. Keadaan yang sangat fleksibel ini dinilai sangat membantu para peserta didik untuk mempercepat penyelesaian studinya.

Peserta didik yang belajar pada lembaga pendidikan konvensional tidak perlu terlalu khawatir lagi apabila tidak dapat menghadiri kegiatan pembelajaran secara fisik karena berbenturan dengan kepentingan lain yang tidak dapat ditinggalkan atau ditangguhkan. Apabila lembaga pendidikan konvensional tersebut menyajikan materi pembelajaran yang dapat diakses para peserta didik melalui internet, maka peserta didik dapat mempelajari materi pembelajaran yang terlewatkan tersebut melalui internet. Hal ini dapat terjadi karena peserta didik diberi kebebasan mengikuti kegiatan pembelajaran yang sebagian disajikan secara tatap muka dan sebagian lagi melalui internet (model pembelajaran kedua). Di samping itu, para peserta didik juga dimungkinkan untuk tidak sepenuhnya menghadiri kegiatan pembelajaran secara fisik. Sebagai penggantinya, para peserta didik belajar melalui internet (model pembelajaran ketiga).

Peranan TIK dalam model pembelajaran tersebut sangat jelas. Hadirnya $e$ learning dengan semua variasi tingkatannya telah memfasilitasi perubahan pola pembelajaran. Secara umum, e-learning dapat didefinisikan sebagai pembelajaran yang disampaikan melalui semua media elektronik termasuk, internet, intranet, extranet, satelit, audio/video tape, TV interaktif, dan CD ROM. Sedangkan secara khusus kaitannya dengan pemanfaatan koneksi internet, e-learning merupakan aplikasi internet yang dapat menghubungkan antara pendidik dan peserta didik dalam sebuah ruang belajar online. ${ }^{9}$ E-learning tercipta untuk mengatasi keterbatasan antara pendidik dan peserta didik, terutama dalam hal waktu, ruang, kondisi, dan keadaan. Melalui e-learning maka pendidik dan peserta didik tidak harus berada dalam satu dimensi ruang dan waktu. Proses pendidikan dapat berjalan kapan saja dengan mengabaikan kedua hal tersebut.

Penggunaan e-learning tidak bisa terlepas dari peran internet. Sistem kerja internet pada dasarnya semisal mengakses sumber informasi yang tersedia pada komputer penyedia, karena adanya jaringan yang luas. Oleh karena itu, e-

9 Deni Darmawan, Pengembangan E-Learning Teori dan Desain, (Bandung: PT. Remaja Rosakarya, 2014), hal. 10

RI'AYAH, Vol. 01, No. 02 Juli-Desember 2016 
learning bisa dilaksanakan karena jasa internet. E-Learning sering disebut pula dengan nama on-line course karena aplikasinya memanfaatkan jasa internet.

Peran lainya, bahwa TIK berperan sebagai mediator dalam pembelajaran yaitu untuk menyebarkan berbagai informasi dengan mudah dan cepat. Pengembangan system pembelajaran dengan internet dapat dilakukan dengan tiga cara, yaitu sebagai berikut:

1. Menggunakan sepenuhnya fasilitas internet yang telah ada, seperti email, internet relay chat, world wide web, search engine, milis (miling list) dan file transfer protocol (FTP)

2. Menggunakan software pengembangan program pembelajaran dengan internet yang dikenal dengan web course, yang diantaranya bisa didapat secara gratis ataupun dengan membelinya. Ada beberapa vendor yang mengembangkan web course tools seperti webCT, Webfuse, TopClass dan lainlain

3. Mengembangkan sendiri program pembelajaran sesuai dengan kebutuhan (tailor-made), dengan menggunakan bahasa pemograman seperti aktif server pages (ASP) dan lain-lain.

Dewasa ini sesuai dengan tahap perkembangannya yang digunakan adalah teknologi maju, seperti audio dan video cassette, overhead projektor, slide film dan motion film, mesin pengajaran, komputer, cd-rom dan internet. ${ }^{10}$ Semua itu adalah wujud nyata peranan teknologi informasi dalam pembelajaran.

Salah satu tantangan terbesar dalam pembelajaran, pada tingkatan apapun, adalah memastikan transpor pengetahuan (dan juga nilai-nilai) dapat berjalan dengan baik. Di berbagai Penelitian mengindikasikan banyak faktor yang terlibat dalam konteks ini, mulai dari bagaimana dosen dan peserta didik memandang pembelajaran, lingkungan akademik, sampai dengan metode pembelajaran yang digunakan. Maka di sinilah peranan dan kontribusi teknologi informasi dan komunikasi dalam pembelajaran menjdi urgen agar peserta didik/peserta didik tidak menjalankan aktivitas pembelajaran yang membosankan, sehingga mereka lebih tertarik terhadap materi/bahan ajar, banyak memperoleh pembanding teori dan konsepnya, mudah dipelajarinya, dan lebih cepat menyerapnya serta melekat dalam ingatannya.

Kajian empirik telah dilakukan beberapa kali di Amerika Serikat yang merupakan tempat lahirnya Teknologi Pendidikan sebagai suatu disiplin ilmu. The Commission on Instructional Technology (suatu komisi nasional yang dibentuk oleh Kementerian Kesehatan, Pendidikan dan Kesejahteraan) ${ }^{11}$ menunjukkan

10 Nana Syaodih Sukmadinata, Pengembangan Kurikulum Teori dan Praktek, (Bandung: Remaja Resdakarya, 2013) hal. 96

11 Sidney Tickton, To Improve Learning, vol. I, Part I, a report by the Commission on Instructional Technologi, (New York: R.R. Bowker Co, 1970) hal. 32-35

RI'AYAH, Vol. 01, No. 02 Juli-Desember 2016 
bahwa teknologi pendidikan memiliki berbagai potensi, di antaranya sebagai berikut:

1. Meningkatkan produktivitas pendidikan dengan jalan memperlaju penahapan belajar, membantu pendidik untuk menggunakan waktunya secara lebih baik, dan mengurangi beban pendidik dalam menyajikan informasi, sehingga pendidik dapat lebih banyak membina dan mengembangkan kegiatan belajar peserta didik.

2. Memberikan kemungkinan pendidikan yang sifatnya lebih individual, dapat dilakukan dengan cara mengurangi kontrol pendidik yang kaku dan tradisional atau konvensional, dan memberikan kesempatan anak didik untuk berkembang sesuai dengan kemampuan perorangan mereka.

3. Memberikan dasar pembelajaran yang lebih ilmiah, dilakukan melalui perencanaan program pembelajaran secara bersistem dan pengembangan bahan ajaran yang dilandasi penelitian.

4. Meningkatkan kemampuan pembelajaran dengan memperluas jangkauan penyajian, dan kecuali itu penyajian pesan dapat lebih konkret.

5. Memungkinkan belajar lebih akrab, karena dapat mengurangi perbedaan antara pelajaran di dalam dan di luar sekolah, juga memberikan pengalaman pertama.

6. Memungkinkan pemerataan pendidikan yang bermutu, terutama dengan dimanfaatkannya bersama tenaga atau kejadian langka dan didatangkannya pendidikan kepada mereka yang memerlukan.

\section{Penutup}

Pesatnya perkembangan ilmu pengetahuan dan teknologi berpengaruh pada multidimensi kehidupan manusia. Semua unsur dituntut siap menghadapi dan mengimbanginya sesuai dengan kapasitasnya masing-masing. Pemerintah dengan kebijakannya harus mampu membaca arah perkembangan tersebut kemudian menentukan kebijakan yang relevan dalam bidang-bidang tertentu.

Bidang pendidikan misalnya, seiring perkembangan IPTEK yang pesat tersbut berpengaruh pada kurikulum, muatan kurikulum harus dapat memenuhi kebutuhan peserta didik untuk menjawab tantangan perkembangan tersebut sehingga dapat mengambil porsi di dalamnya. Dikembangkannya kurikulum bukan berarti akan secara otomatis menyelesaikan masalah, justru akan timbul masalah baru, salah satu masalah yang akan timbul adalah alokasi waktu yang terbatas untuk menyajikan muatan kurikulum yang banyak. Muatan kurikulum bertambah, tetapi alokasi waktu yang tersedia tidak bertambah justru cenderung berkurang, sebab waktu yang ada harus dibagi kembali dengan pertambahan muatan kurikulum. Dalam masalah ini tuntutan percepatan tranformasi bahan ajar dengan alokasi waktu yang singkat, bagimna upayanya agar transformasi bahan ajar tersebut dapat diselesaikan.

RI'AYAH, Vol. 01, No. 02 Juli-Desember 2016 
Teknologi informasi dan komunikasi (TIK) yang salah satu kedudukannya sebagai Virtual University, menawarkan solusi alternatif untuk menjawab dan menyelesaikan masalah tersebut. TIK merupakan sarana prasarana yang digunakan untuk menyimpan, menyusun, memperoleh, mengirimkan informasi atau data-data yang digunakan untuk kepentingan pribadi, pendidikan ataupun binis secara mudah dan cepat. TIK digunakan untuk memudahkan kerjasama antara pendidik dan peserta didik dalam pembelajaran dan layanan pendidikan lainnya, dapat dilakukan melalui internet yaitu dengan menyediakan bahan ajar dan mengirimkannya melalui jaringan internet secara online, kemudian peserta didik dapat mengaksesnya kapanpun dan di manapun berada.

\section{Daftar Pustaka}

Bambang Warsita, Teknologi Pembelajaran, Jakarta: Rineka Cipta, 2008

Daryanto, Media Pembelajaran Perannya Sangat Penting dalam Mencapai Tujuan Pembelajaran, Yogyakarta: Gava Media, 2013

Deni Darmawan, Biologi Komunikasi; Komunikasi Pembelajaran berbasis Brain Information Comunication Technology, Bandung: Humaniora, 2009 Pengembangan E-Learning Teori dan Desain, Bandung: PT. Remaja Rosakarya, 2014

, Teknologi Pembelajaran, Bandung: PT. Remaja Rosakarya, 2024

Kementerian Negara Riset dan Teknologi, Buku Putih, Penelitian Pengembangan dan Penerapan IPTEK Bidang Teknologi Informasi dan Komunikasi Tahun 2005-2025, Jakarta: Kementerian Negara Riset dan Teknologi, 2006

Nana Syaodih Sukmadinata, Pengembangan Kurikulum Teori dan Praktek, Bandung: Remaja Resdakarya, 2013

Siahaan, E-Learning (Pembelajaran Elektronik) sebagai Salah Satu Alternatif Kegiatan Pembelajaran, Jurnal Pendidikan dan Kebudayaan, No. 042, tahun ke-9, Mei 2003

Sidney Tickton, To Improve Learning, vol. I, Part I, a report by the Commission on Instructional Technologi, New York: R.R. Bowker Co, 1970

Yusufhadi Miarso, Menyemai Benih Teknologi Pendidikan, Jakarta: Kencana, 2014

RI'AYAH, Vol. 01, No. 02 Juli-Desember 2016 